\title{
IOWANS HONORED IN NAMING VESSELS
}

\section{Statesmen and War Heroes Share Distinction in DESIGNATION OF NEW SHIPS}

Hardly had the last of the world War I destroyers been disposed of by the United States government under the lend-lease arrangement in exchange for landing bases upon British possessions, as authorized by congress, when newly constructed Liberty ships commenced to slide down from the shipways and ply the far-flung supply lines to docks and bases on friendly foreign shores. Also, new navy vessels took form and received war equipment and mountings in the United States ship yards that skirt the Atlantic, the Pacific and the Gulf of Mexico.

The latest OWI figures obtainable reveal that in our crucial global engagement with the Axis powers, the United States has built and launched 2,897 merchant ships between December 7, 1941 and February 10, 1944, an average of nearly four vessels daily. Also there were vast fleets of new war vessels constructed and launched, the number and character of which are not being revealed. The Liberty ships first constructed rapidly came from the builders and were quickly commissioned, and later followed the Victory models named for the Allied countries.

In the selection of names honored in history from the war and navy annals of the past, as well as of heroes of the present war, to designate these ships, Iowa has furnished her share. Names familiar in the households of the Hawkeye state, as well as of men heretofore unknown, but whose deeds of valor have blazoned across the headlined pages of newspapers and magazines, are now gracing the bows of staunch crafts being christened every week.

The vessels constructed in the United States navy yards come under long established general classifications. Battleships are named for states; cruisers and frigates for cities; submarines for fish; destroyers and destroyer escorts for officers or enlisted men in the navy, former sec- 
retaries of the navy, members of congress or inventors; carriers for historical vessels or battles; mine sweepers for birds; gun boats for small cities; sea plane tenders for sounds or bays; ocean-going tugs for Indian tribes; and cargo ships for stars. Maritime Commission vessels are named for individuals.

Just recently it was announced that after completion of the list of names of the Allied countries in designating the Victory ships, those next leaving the shipways will bear the names of fifty cities of varied size in scattered sections of the country selected as typical and historical, and will be built by three Pacific coast shipyards. In each instance the city's name will be followed by the word "Victory." Among them will be "Carroll Victory" named in honor of Carroll, Iowa, this state receiving the first such honor and distinction.

\section{Those Named Honoring Iowa}

We have compiled information about the various vessels, both navy fighting craft and maritime commission transport and cargo ships, bearing names honoring Iowa, places in Iowa or Iowa persons, and present below the list completed to June 1, 1944. Through the kind offices of Senator George A. Wilson, the Secretary of the Navy, James Forrestal has had the list checked and approved, and additional facts given.

The list includes thirty-two vessels. Of these there is one battleship, one cruiser, two destroyers, two frigates, one attack transport, eleven destroyer escorts. These are all vessels of the fighting force of the United States navy.

The list also includes, of the vessels built by the United States Maritime Commission, for auxiliary purposes, fourteen ships, of which two are listed as cargo ships. These are all Liberty ships, classified as EC-2, deadweight tonnage 10,800, length 44 feet, 6 in., cargo tonnage 9,146 , horsepower 2,500, making 11 knots.

The Navy Department states that the newest type of ship in the United States navy is the destroyer escort, especially designed for the job of convoy protection. They 
are about 300 feet long, fully armed and take over much of the duty formerly served by the larger destroyers. The name frigate has been revived for a twin-screw corvette, with a length of about 300 feet, fully armed.

The list of Iowa named vessels launched since the beginning of World War II follows:

\section{BATTLESHIP}

U. S. S. IOWA IV, Battleship 61, named for State of Iowa, launched New York Navy yard, Aug. 27, 1942; sponsor, Mrs. Henry A. Wallace, wife of the vice president.

\section{CRUISER}

U. S. S. DES MOINES, Cruiser CA-75, named for City of Des Moines, keel laid Sept. 9, 1943, not yet launched; Bethlehem Steel Co., Quincy, Mass.

\section{Frigates}

U. S. S. BURLINGTON, Frigate PF-51, named for City of Burlington, Iowa, launched Dec. 7, 1943; sponsor, Mrs. Florence Conrad, wife of Max A. Conrad, mayor of City of Burlington; Consolidated Steel Co., Wilmington, Cal.

U. S. S. DAVENPORT, Frigate PF-69, named for City of Davenport, Iowa, launched Dec. 8, 1943; sponsor, Mrs. Ed. Frick, wife of mayor of Davenport; Leathem D. Smith Shipbuilding Co., Sturgeon Bay, Wis.

\section{DESTROYERS}

U. S. S. REMEY, Destroyer 688, named in honor of Rear Admiral George Collier Remey, USN, of Iowa; launched July 25, 1943; sponsor, Angelica C. Remey, daughter of the admiral; Bath Iron Works, Bath, Maine.'

U. S. S. THE SULLIVANS, Destroyer 537, named in honor of the five Sullivan boys of Waterloo, Iowa, lost on the Cruiser Juneau; launched April 4, 1943; sponsor, Mrs. Thomas F. Sullivan, mother; Bethlehem Co., San Francisco.

\section{ATTACK TRANSPORT}

Former U. S. S. ANSEL BRIGGS, now the U. S. S. MINTAKA, Attack Transport AK-94, named in honor of Iowa's first state governor; launched March 10, 1943; sponsor, Mrs. A. V. Bechtel, wife of shipbuilder; California Shipbuilding Corp., Wilmington, Cal. 


\section{DESTROYER ESCORTS}

U. S. S. BUNCH, Destroyer Escort 694, named in honor of Kenneth Cecil Bunch, aviation radioman first class, of Pershing, U. S. navy, killed in South Pacific; launched May 29, 1943; sponsor, Mrs. Leila Mae Bunch, Pershing, Iowa, wife; Defoe Shipbuilding Co., Bay City, Mich.

U. S. S. DURANT, Destroyer Escort 389, named in honor of Kenneth William Durant, pharmacist's mate, third class, U. S. navy, Algona; launched Aug. 3, 1943; sponsor, Mrs. Solomon R. Durant, mother; Brown Shipbuilding Co., Houston, Texas.

U. S. S. GRISWOLD, Destroyer Escort 7, named in honor of hero of Battle of Midway, Ens. Don T. Griswold, U. S. N. R. of Clarinda; launched Jan. 9,1943; sponsor, Mrs. Don T. Griswold, Sr., mother; Boston Navy Yard.

U. S. S. HILBERT, Destroyer Escort, named in honor of . Ernie Hilbert, killed in action in battle of Midway; sponsor, Mrs. Thomas Hilbert, El Monte, California, mother.

U. S. S. KEPHART, Destroyer Escort 207, named in honor of Lt. William Perry Kephart, U. S. N. R. of Des Moines, killed in action while piloting navy plane at Guadalcanal; launched Sept. 6, 1943; sponsor, Mrs. Adam Perry Kephart, mother; Charleston Navy Yard, Charleston, S. C.

U. S. S. MACK, Destroyer Escort 358, named in honor of Harold John Mack, Le Mars, Iowa, gunner's mate, second class, U. S. navy; launched April 11, 1944, sponsor, Mrs. Gertrude Mack, Los Angeles, mother; Consolidated Steel Co., Ltd., Orange, Texas.

U. S. S. MYERS, Destroyer Escort 595, named in honor of Merton Bernell Myers, machinist's mate, first class, U. S. navy, of Pocahontas; launched Feb. 15, 1944; sponsor, Mrs. Ralph W. Myers, mother; Bethlehem-Hingham Shipyard, Inc., Hingham, Mass.

U. S. S. REYNOLDS, Destroyer Escort 42, named in honor of Dudley Louis Reynolds, Fort Dodge, Ens. U. S. navy; launched Aug. 1, 1943; sponsor, Mrs. Nora Lou Reynolds, wife; Puget Sound Navy Yard, Seattle, Wash.

U. S. S. SCHMITT, Destroyer Escort 676, named in honor of Father Herman Aloysius Schmitt, Lt. (j. g.) chaplain's corps U. S. navy, of St. Lucas and Dubuque, who went down on the Oklahoma at Pearl Harbor; launched May 29, 1943; sponsor, Mrs. Elizabeth Bucheit, St. Lucas, Iowa, sister; Bethlehem-Fore River, Quincy, Mass.

U. S. S. SELLSTROM, Destroyer Escort 255, named in honor of Ens. Edward Robert Sellstrom of Rockwell City, who lost his life in airplane crash; launched May 12, 1943; sponsor, Miss Genevieve Dahl, his fiancee, Minneapolis; Brown Shipbuilding Co., Houston, Texas.

U. S. S. SUESENS, Destroyer Escort 342, named in honor of 
Lt. (j.g.) Richard Wayne Suesens, of Burlington, navy flier killed in action in Pacific area; launched Jan. 11, 1944; sponsor, Mrs. Margaret Jean Suesens, wife; Consolidated Steel Corp., Ltd., Orange, Texas.

U. S. S. WEBER, Destroyer Escort 675, named in honor of Ens. Frederick Thomas Weber, U. S. N., of Des Moines, killed in action in Battle of Midway; launched May 1, 1943; sponsor, Mrs. Matt R. Walsh, Galesburg, Ill., mother; Bethlehem-Fore River, Quincy, Mass.

\section{MARITIME COMMISSION VESSELS}

S. S. WILLIAM B. ALLISON, Liberty Ship, named in honor of Iowa United States senator; launched March 8, 1943; sponsor, Mrs. Bennet Rose; California Shipbuilding Corp., Wilmington, Cal.

S. S. ALBERT B. CUMMINS, Liberty Ship, named in honor of Iowa Governor and United States senator; launched March 23, 1943; Oregon Shipbuilding Corp., Portland, Ore.

S. S. FRANK CUHEL, Liberty Ship, named in honor of a war correspondent from Cedar Rapids, Iowa; launched Dec. 15, 1943; sponsor, Miss Ermengarde Cuhel, sister; built at Richmond, Cal.

S. S. JULIEN DUBUQUE, Liberty Ship, named in honor of first settler of City of Dubuque; launched Feb. 16, 1943; built at Richmond, Cal.

S. S. LEO DUSTER, Liberty Ship, named in honor of secretary to the governor of Iowa, deceased, of Cedar Rapids; financed by Linn Co. drive; launched Nov. 21, 1943; sponsor, Mrs. Leo Duster, wife; Bethlehem-Fairfield Shipyards, Baltimore, Md.

S. S. JOSIAH B. GRINNELL, Cargo Ship, named in honor of founder of City of Grinnell; launched March 4, 1943; built at Richmond, Cal.

S. S. SAMUEL J. KIRKWOOD, Liberty Ship, named in honor of Iowa governor and United States secretary of the interior; launched Dec. 3, 1943; built at New Orleans.

S. S. W. W. McCRACKIN, Liberty Ship, named in honor of resident of Fairfield, Iowa; launched Oct. 8, 1943; built at Portland, Ore.

S. S. EDWIN T. MEREDITH, Liberty Ship, named in honor of Iowa publisher and secretary of agriculture; launched June 15, 1943; built at Richmond, Cal.

S. S. JOHN H. QUICK, Liberty Ship, named in honor of Herbert Quick, Iowa author; launched Dec. 13, 1943; California Shipbuilding Corp., Wilmington, Cal.

S. S. LESLIE M. SHAW, Liberty Ship, named in honor of Iowa governor and secretary of the treasury; launched Dec. 22, 1942; built at Richmond, Cal.

S. S. HENRY C. WALLACE, Liberty Ship, named in honor of Iowa publisher and secretary of agriculture; launched Aug. 15, 
1943; sponsor, Mrs. B. B, Hickenlooper, wife of the Iowa governor; built at Wilmington, Cal.

S. S. JAMES B. WEAVER, Cargo Ship, named in honor of Iowa member of congress, publicist and Civil War soldier; launched March 23, 1943; built at Wilmington, Cal.

S. S. ROBERT G. COUSINS, Liberty Ship, named in honor of Iowa congressman; launched Dec. 23, 1943; built at Richmond, Cal.

\section{THE AGUE IN IOWA}

It is well known that all along the American frontier as the virgin soil was being turned over for the first time, there was a disposition to epidemics of the fevers and chills, and Iowa suffered from this in early days. It has been declared that at least some of the emigration from the Mississippi valley to the Oregon country a hundred years ago was hastened by the prevalence of illness in the new country. A footnote to an article on the Oregon trail in No. 94 of the Columbia Studies in History, Economics and Public Law, quotes a letter by R. Bond, M.D., dated August 25, 1845, to the American Bible Society, written from Iowa saying:

"Such was the sickness here (Van Buren county) that there was scarcely any business done in any stores of this place, except at the drug stores and the groceries. Religious meetings on the Sabbath were suspended for lack of hearers, all of whom were sick, or engaged in taking care of the sick. Our physicians say that some of their patients died for want of proper care and nursing. A sufficient number of persons in health could not be found to take care of them."

\section{EARLY Y. M. C. A. ACTIVITY}

Journal of the Iowa Census Board August 29, 1868:

Resolved, that permission be given to the Young Men's Christian Association to occupy the main stand in Capital Square, and the grounds within 120 yards thereof, on each Sabbath afternoon, for religious exercises, until otherwise ordered by the Census Board. 
Copyright of Annals of Iowa is the property of State of Iowa, by \& through the State Historical Society of Iowa and its content may not be copied or emailed to multiple sites or posted to a listserv without the copyright holder's express written permission. However, users may print, download, or email articles for individual use. 